\title{
Tworzenie polskich kołchozów narodowościowych w ramach kolekty- wizacji rolnictwa na Podolu w latach 20. i 30. XX w. Przyczynek do dziejów rolnictwa na radzieckiej Ukrainie
}

\section{Creating Polish National Collective Farms as}

a Part of Collectivization of Agriculture in Podole in the 1920 s and 1930s. Contribution to the History of Agriculture in Soviet Ukraine

\section{Wprowadzenie}

Przymusowa kolektywizacja rolnictwa, wpisująca się w myśl polityki leninowsko-stalinowskiej i będąca jednym z jej zasadniczych celów, które w myśl Manifestu komunistycznego Karola Marksa i Fryderyka Engelsa „mogą być osiągnięte jedynie przez obalenie przemocą całego dotychczasowego ustroju społecznego"', została przeprowadzona w ZSRR na ogromną skalę. Terror zaś stał się jednym z podstawowych narzędzi służących do zmiany stosunków własnościowych i sposobu gospodarowania w rolnictwie. Proces kolektywizacji objął obszar Ukrainy, w tym rzesze Polaków na Podolu zamieszkujących te ziemie od pokoleń. Sam proces przekształcania indywidualnych gospodarstw w spółdzielnie rolnicze przebiegał w kilku etapach. W efekcie doprowadził on do załamania produkcji rolnej oraz wielkiego głodu na Ukrainie. Specyficznym działaniem władz komunistycznych w walce o kolektywizację było tworzenie rad wiejskich i kołchozów narodowościowych.

* Кам'янець-Подільський Національний університет ім. Івана Огієнка, Факультет іноземної філології, Кафедра слов'янської філології та загального мовознавства

I K. Marks, F. Engels, Manifest Komunistyczny, Warszawa 1948, s. 78. 
Tematyka kolektywizacji rolnictwa oraz represji antypolskich na Ukrainie w czasach stalinowskich doczekała się w ostatnich trzech dekadach szeregu publikacji naukowych. Wśród opracowań polskojęzycznych na pierwszym miejscu należy wymienić monografię Roberta Kuśnierza² ${ }^{2}$ która w sposób w miarę pełny prezentuje problematykę kolektywizacji i wielkiego głodu na Ukrainie. Należy również zwrócić uwagę na prace Mikołaja Iwanowa ${ }^{3}$, Henryka Strońskiego ${ }^{4}$ czy Romana Dzwonkowskiegos. Z opracowań ukraińskojęzycznych nie można pominąć ważnej pracy Stanisława Kulczyckiego, badacza ukraińskiego, który jako pierwszy, już w latach 80. Xxw., wydał monografię o tragedii wsi ukraińskiej i zwrócił uwagę na ludobójczy charakter stalinowskiej polityki wobec wsi i chłopów ukraińskich w latach 30. XX stulecia ${ }^{6}$. Warto także przywołać publikacje Leonida Misinkiewicza ${ }^{7}$ dotyczące polskiej mniejszości w obwodzie chmielnickim. Niezwykle cennym źródłem informacji na temat procesu tworzenia produkcyjnych spółdzielni rolniczych jest zbiorowa praca wydana przez Ukraiński Instytut Pamięci Narodowej (Український інститут національної пам'яті України) poświęcona ofiarom Wielkiego Głodus. Autorzy na podstawie zbiorów Państwowego Archiwum Obwodu Chmielnickiego dokonali opisu przebiegu oraz następstw kolektywizacji na Podolu.

Badania dotyczące sytuacji na Ukrainie w latach 30. Xx w. zaowocowały również publikacjami źródłowymi. Wśród wydawnictw polskojęzycznych

2 R., Kuśnierz, Ukraina w latach kolektywizacji i Wielkiego Gtodu (1929-1933), Toruń 2005.

3 M. Iwanow, Pierwszy naród ukarany. Polacy w Zwiazku Radzieckim 1921-1939, Warszawa 1991.

4 H. Stroński, Represje stalinizmu wobec ludności polskiej na Ukrainie w latach 1929-1939, Warszawa 1998; tenże, Nieudany eksperyment. Treść, formy i skutki sowietyzacji ludności polskiej na Ukrainie w latach 20. i $30 . X X$ wieku, [w:] Polska droga do Kazachstanu. Materiaty z międzynarodowej konferencji naukowej, Żytomierz I2-I4 października Ig96r., Warszawa 1998.

5 R. Dzwonkowski, Gtód i represje wobec ludnościpolskiej na Ukrainie (1932-1933, 1946-1947), „Teka Komisji Historycznej” Polska Akademia Nauk Oddział w Lublinie 20I2, vol. IX, s. 203-222. Dostępny w internecie:, https://journals.pan.pl/Content/92799/mainfile.pdf?handler=pdf. (dostęp: Is maja 2020); tenże, Marchlewszczyzna, [w:] Encyklopedia Katolicka, t. II, Lublin 2006.

6 Polskie wydanie monografii ukazało się dzięki Kolegium Europy Wschodniej im. Jana Nowaka-Jeziorańskiego, zob. S. Kulczycki, Hotodomor. Wielki gtód na Ukrainie w latach 1932-1933 jako ludobójstwo - problem świadomości, przekład B. Salej, Wrocław 2008.

$7 \Lambda$. Місінкевич, Єврейська і польська національні меншини Поділля (20-30-тірр. хХ століття), Подімля 200I; tenże, Реабілітація жертв політичних репресій в Украӥні (друга половина XX - початок ХХІ століття), Хмемьницький 2009; tenże, Польські сільські ради на Поділлі в гого-гузо-ті роки, [w:] Поляки на Хмельниччині: погляд крізь віки. Збірник наукових праць за матеріалами міжнародної конференцї (23-24 червня I9g9 року), Хмемьницький 1999; tenże, Процеси реабілітації в Україні жертв політичних репресій радянської доби, [w:] Реабілітовані історією. Хмельницька область, т. 27, Хмемьницький 2015; $\Lambda$. Місінкевич, Коренізація і національні меншини Поділля у 20-30-х рр. ХХ столітms, [w:] Реабілітовані історією. РіАний Край, Київ г999.

8 Національна Книга пам'ятіжертв Голодомору 1932-1933рр. В Україні. Хмельницькаобласть, Хмельницький 2008. 
na uwagę zasługuje wydawana przez Południowo-Wschodni Instytut Naukowy seria Polacy na Ukrainie`. Szczególnie ważnym dla poznania losów ludności ukraińskiej i polskiej w latach 30. Xx stulecia są wspomnienia zebrane przez Piotra Jaszczuka, opublikowane Kijowie i Nowym Jorku w roku $1999^{\mathrm{IO}}$, dotyczące dramatycznej sytuacji ludności na Ukrainie radzieckiej w okresie przemian na wsi i wielkiego głodu z początku lat 30.

Celem niniejszego artykułu jest przedstawienie zasad i skutków wprowadzania kolektywizacji na Podolu, ukazanie procesu tworzenia wiejskich rad i kołchozów narodowościowych. W artykule opisano akty prawne, na mocy których wdrażano zmiany w rolnictwie, ogólny zarys przebiegu kolektywizacji na Podolu oraz zaprezentowano formy uspółdzielczania rolnictwa w okręgu kamieniecko-podolskim.

\section{Założenia programowe i podstawy prawne kolektywizacji}

W listopadzie ı918 r. przywódca rosyjskich komunistów Włodzimierz Lenin wskazał, że źródłem wyzysku na wsi byli bogaci chłopi -

kułacy i pasożyci wiejscy, którzy zbogacili się na wojnie, którzy wykorzystywali głód, aby sprzedać po bajecznych cenach zboże, chowali je spodziewając się nowej zwyżki cen, i wszelkimi sposobami starają się teraz zbogacić na niedoli, na głodzie wiejskich biedaków i miejskich robotników. [...] kułacy i pasożyci - to nie mniej straszny wróg niż kapitaliści i obszarnicy ${ }^{\mathrm{II}}$.

Nawoływał więc do rozprawienia się z wrogiem i przestrzegał: ,jeżeli kułak pozostanie nietknięty, jeżeli nie zwyciężymy pasożytów, to niechybnie powróci znów car i kapitalista [...] rewolucja nieuchronnie ponosi klęskę, jeżeli chłopstwo nie zwycięży kułackiego panowania"'2. Środkiem do osiągnięcia celu, poza rozprawieniem się z kułakami, miały być komuny, uprawa zespołowa, stowarzyszenia chłopskie. Od I92 I r. w celu zapobiegnięcia głodowi, który zebrał w kraju kilkumilionową rzeszę ofiar, W. Lenin, a po jego śmierci Józef Stalin, odeszli od realizacji nakreślonego wcześniej planu kolektywizacyjnego. W ramach Nowej Ekonomicznej Polityki zaczęto odbudowywać radzieckie rolnictwo. Kres temu procesowi położyły

9 Polacy na Ukrainie, red. S. Stępień, t. I-II: Lata 1917-1939, Przemyśl 1998-2019.

го П. Ящук, Портрет Темряви. Свщчення, документа і матеріали (у двох книгах), t. I-2, Київ-Нью Йорк 1999.

II W. Lenin, Przemówienie do delegatów Komitetów Biedoty Obwodu Moskiewskiego, 8.XI.IgI8, [w:] tenże, O spótdzielczości produkcyjnej na wsi, Warszawa I949, s. IO-II.

I2 Tamże, s. I2-I3. 
decyzje z końca lat 20. o intensywnej industrializacji, która w krótkim czasie miała doprowadzić do uniezależnienia i samowystarczalności ZSRR. Nowa polityka przyspieszyła przemiany ustrojowe na wsi. Jej obraz miał zostać zmieniony przez szybkie przekształcenie gospodarstw indywidualnych w duże, zmechanizowane gospodarstwa kołchozowe. W tym czasie pojawiły się problemy w zaopatrzeniu rynku, za które odpowiedzialnością władze obarczyły chłopstwo. W konsekwencji stało się to jedną z przyczyn podjęcia na początku października 1929 r. decyzji o powszechnej kolektywizacji rolnictwa. Wykładnię działania w tym zakresie J. Stalin przedstawił na łamach „Prawdy” 7 XI 1929 r. Trzy dni później oficjalną decyzję ogłosiło plenum Wszechrosyjskiej Komunistycznej Partii (bolszewików) - WKP(b), a plan masowej kolektywizacji, który miano zrealizować w ciągu półtora do dwóch lat opracowała powołana w grudniu komisja ${ }^{13}$.

Podstawą urzeczywistniania polityki kolektywizacji na Ukrainie stał się dekret Ogólnoukraińskiego Centralnego Komitetu Wykonawczego z 26 V 1919 r. O socjalistycznym gospodarowaniu ziemia i środkach przejścia na rolnictwo socjalistyczne oraz późniejsze uchwały WKP(b). W grudniu 1927 r. przyjęto rezolucję $O$ pracy na wsi, a 5 I 1930 r. uchwalono postanowienie Komitetu Centralnego WKP(b) O tempie kolektywizacji $i$ środkach pomocy państwa w budowaniu kotchozów. Zniszczeniu zamożnego chłopstwa, w tym ukraińskiego jako klasy kułaków, miały służyć dyrektywy KC WKP(b): O wzroście dostaw zboża z 6 I $1928 \mathrm{r}^{\text {I4 }}$ Stosowanie represji wobec chłopstwa przybrało charakter najbardziej masowy po ukazaniu się uchwały Biura Politycznego KC WKP(b) O przedsięwzięciach zmierzających do likwidacji kutackich gospodarstw w rejonach przyśpieszonej kolektywizacji z 30 I 1930 r. Dzień później, I II 1930 r., wydano postanowienie Zjednoczonego Zarządu Państwowo-Politycznego (ogPu) przy Radzie Komisarzy Ludowych ZSRR $O$ środkach dotyczacych zmiany socjalistycznej przebudowy gospodarstw wiejskich w rejonach przyśpieszonej kolektywizacji i walki z kutactwem $^{15}$. Mechanizm i technologię „rozkułaczania” zawarto w rozkazie OGPU nr 44/2I z 2 II 1930 r. O środkach likwidacji kutactwa jako klasy. W tym ostatnim zawarto złowrogą zapowiedź działań komunistycznej władzy: „w najbliższym czasie kułakowi, zwłaszcza jego bogatej kontrrewolucyjnej

I3 R. Conquest, The Harvest of Sorrow. Soviet collectivization and the terror-famine, New York-Oxford 1986, s. 87-188.

I 4 П. Я. Слободянюк, Голодомори в Україні якзасібвинищення Українства, [w:] Національна Kнuza..., s. 9. Dostępny w internecie: http://www.memory.gov.ua:8080/data/upload/publication/main/ua/I090/42.pdf [dostęp: 30 maja 2020].

I5 G.P. Cwietkow, Sowieckie ustawodawstwo i organy represji w latach 20-30. XX wieku, „Zesłaniec” 2008 , nr 33, s. 66 . 
części, powinien zostać zadany miażdżący cios. Opór kułaka powinien być i będzie ostatecznie złamany”.

W ramach programu kolektywizacyjnego terytorium ZSRR podzielono na regiony i wyznaczono terminy przeprowadzenia akcji: „rejon Powołża (Dolnej Wołgi) zamierzano skolektywizować do jesieni 1930 roku, rejon Centralnego Czarnoziemu i Stepów Ukrainy - do jesieni i93I r., lewobrzeżną Ukrainę do wiosny 1932 r., rejony Północy i Syberii - do roku $19333^{\text {"I6 }}$.

Jak pisał Romuald Turkowski:

Stalin ogłosił początek „nowej rewolucji”, podkreślając konieczność szybkiego tempa kolektywizacji rolnictwa. [...] owej „odgórnej rewolucji” towarzyszyły dwa zjawiska: „rozkułaczanie” i tworzenie kołchozów. Rozkułaczanie miało dostarczyć bazy materiałowej dla kolektywizacji; do połowy 1930 roku „rozkułaczono” ponad 320 tysięcy gospodarstw, a ich mienie przekazano kołchozom, jako wkład parobków i biedoty; likwidacja kułaków pozbawiła wieś najbardziej przedsiębiorczych i niezależnych chłopów, oraz - co równie istotne - osłabiła ducha oporu mieszkańców wsi ${ }^{17}$.

\section{Rozkułaczanie i kolektywizacja na Ukrainie}

Przystępując do realizacji planu rozwoju przemysłowego kraju realizowanego w ramach pierwszego planu pięcioletniego, wykorzystując przepisy z początku 1930 r., przystąpiono do rozkułaczania wsi. J. Stalin, jak zgodnie twierdzą historycy, doskonale zdawał sobie sprawę z tego, że nakazana przez niego likwidacja kułactwa oznaczała wyrok śmierci na miliony ludzi ${ }^{18}$. Zaliczenie do grupy „kułaków”, „podkułaczników” czy „wrogów ludu" na wsi nie opierało się na kryteriach majątkowych, np. posiadaniu przez nich własności rolnej o określonym obszarze czy uzyskiwanych dochodach. Byli do nich kwalifikowani zarówno posiadacze dużych gospodarstw, jak i umierający z głodu nędzarze, osoby posiadające lepszą chatę czy praktykujący wiarę ${ }^{19}$. W praktyce o tym, kto jest kułakiem, decydowało państwo. Policja państwowa otrzymała uprawnienia do sprawdzenia całej populacji wiejskiej na terenie kraju. Z kolei tak zwane trójki - składające się z funkcjonariusza policji, miejscowego przywódcy partyjnego

\footnotetext{
I6 M. Smoleń, Kolektywizacja rolnictwa w ZSRR, [w:] Encyklopedia „biatych plam”, Radom 2002, s. 228.

I7 R. Turkowski, Przejawy propagowania radzieckiego modelu gospodarowania na wsi przez komunistyczny aparat propagandowy w Polsce w latach 1948-1956, , Rocznik Historyczny Muzeum Historii Polskiego Ruchu Ludowego" 2019, nr 35, s. 140.

I8 F. Bernaś, J.E. Wilczur, Piekielny krąg. Zdziejów CZEKA, GPU, NKWD, Warszawa b.r.w., s. 70-73.

I9 R. Dzwonkowski, Gtód..., s. 206.
} 
i prokuratora - miały prawo do decydowania o nakładanych na chłopów represjach, do których należały zesłanie i śmierć. Jeden z lokalnych działaczy partyjnych przyznawał: „Podczas plenów wiejskiej rady tworzymy kułaków według własnego uznania”" ${ }^{20}$. Na władzach lokalnych spoczywał obowiązek wykonywania norm wyznaczających zakres eliminacji indywidualnych gospodarstw chłopskich oraz intensywności usuwania ze wsi bogatszych gospodarzy oraz wszystkich chłopów opierających się kolektywizacji.

W pierwszych czterech miesiącach $1930 \mathrm{r}$. z radzieckiej Ukrainy przymusowo wywieziono II3,6 tys. ludzi zakwalifikowanych jako kułaków. Oznaczało to opróżnienie około trzydziestu tysięcy chat chłopskich. Ogółem spośród I,7 mln osób deportowanych do osad specjalnych na Syberii w europejskiej części zSRR i w Kazachstanie około 300 tys. stanowili chłopi ukraińscy ${ }^{21}$.

Drugim elementem zmian dokonywanych na wsi radzieckiej była likwidacja gospodarstw indywidualnych i tworzenie kołchozów przejmujących całość dotychczasowego majątku chłopa. Działania władz komunistycznych spotkały się z niezadowoleniem chłopów, wśród których szerzyły się bierny opór i bunty. Padały ofiary śmiertelne. Reakcją na przymus kolektywizacyjny była przeprowadzana przez chłopów rzeź inwentarza żywego, zapobiegająca przejmowaniu go przez kołchozy ${ }^{22}$. Zakładanie kołchozów spotkało się z największym oporem ludności na radzieckiej Ukrainie. Dotyczyło to szczególnie ludności polskiej skupionej w trzech obwodach: kamieniecko-podolskim, winnickim i żytomierskim.

\section{Radzieckie eksperymenty narodowo-gospodarcze wobec Polaków na Ukrainie}

Po zakończeniu wojny polsko-bolszewickiej i ustanowieniu granicy między Rzeczpospolitą i Rosją radziecką, część ludności polskiej znalazła się poza granicami państwa na terenach zachodniej Ukrainy i zachodniej Białorusi. Według oficjalnych źródeł liczbę Polaków na Ukrainie obliczano na powyżej 476,4 tys. W latach 20. XX w. władze radzieckie zdecydowały się na prowadzenie polityki narodowościowej w imię lansowanego w ówczesnej propagandzie hasła „Kraju Rad jako państwa bez ucisku narodowego” oraz powtarzanego przez ludowego komisarza do spraw narodowości w rządzie

20 Cyt. za: T. Synder, Skrwawione ziemie. Europa między Hitlerem a Stalinem, przekład B. Pietrzyk, Kraków 2018, s. 52.

2I Tamże, s. 53-54.

22 J. Luszniewicz, Gospodarka radziecka w latach I9I7-194I, [w:] Powszechna historia gospodarcza I9I8-I99I, pod red. W. Morawskiego, Warszawa I994, s. I02. 
centralnym J. Stalina frazesu o „jedności w różnorodności”. Rzeczywistym celem polityki narodowościowej bolszewików wobec Polaków była ich sowietyzacja ${ }^{23}$. W roku 1925, w ramach polityki zakorzenienia komunizmu, na obszarze radzieckiej Ukrainy utworzono Polski Rejon Narodowościowy ze stolicą w Marchlewsku we wschodniej części Wołynia, gdzie według spisu z 1926 r. mieszkało 4I tys. ludzi, w tym 28 tys. Polaków. Sowietyzacji tamtejszej ludności narodowości polskiej, realizowanej przy pomocy polskich komunistów zamieszkujących te tereny, miały służyć: „tworzenie szkolnictwa polskiego, wydawanie gazet i książek polskojęzycznych, wydzielenie narodowościowych rad wiejskich w polskich wsiach, powstanie polskich biur przy komitetach partyjnych, powołanie polskich klubów robotniczych $\mathrm{i}$ innych instytucji kulturalno-oświatowych" ${ }^{24}$.

Podejmowana w latach 20. polityka kolektywizacji polegająca na tworzeniu na początku komun, a potem kołchozów, nie powiodła się. Odsetek skolektywizowanych gospodarstw we wsiach polskich przez długi czas był na niskim poziomie. Zaważyło na tym, z jednej strony, negatywne nastawienie ludności do tej formy organizacji gospodarstw, z drugiej zaś kolektywizacji nie sprzyjał system chutorów. Pierwszy kołchoz powstał na Marchlewszczyźnie dopiero w 1929 r. Dwa lata później, w wyniku nowej polityki kolektywizacyjnej i walki z kułactwem, było ich 26. Skolektywizowano wówczas $16 \%$ gospodarstw ${ }^{25}$.

Na początku lat 30. władze komunistyczne planowały utworzenie jeszcze jednego, poza Marchlewszczyzną (i Dzierżyńszczyzną na Białorusi), polskiego rejonu narodowościowego. Stolicą rejonu miała zostać wieś Hreczany na Podolu, gdzie Ioo\% ludności stanowili Polacy. W ramach planowanej jednostki za zgodą władz centralnych za jedno z podstawowych kryteriów w określeniu przynależności narodowej uznano czynnik religijny (katolicyzm). Istotnym elementem, który w zamyśle twórców projektu miał skłonić władze komunistyczne do zaakceptowania planu, był stosunkowo wysoki w tym okresie, w porównaniu z Marchlewszczyzną, poziom kolektywizacji na tym terenie oraz znaczący udział robotników polskiego

23 Szerzej zob.: M. Iwanow, dz. cyt.; J. M. Kupczak, Polacy na Ukrainie w latach 1921-1939, „Acta Universitatis Wratislaviensis. Politologia” 1994, t. XII; H. Stroński, Nieudany eksperyment..., s. 7-23; Polacy na Ukrainie, t. 9: Zbiór dokumentów, cz. 1: Lata 1917-1939, Przemyśl 2019, s. 8.

24 H. Stroński, Marchlewszczyzna. Rzecz o Polskim Rejonie Narodowościowym na Ukrainie w latach 1925-1935, „Echa Przeszłości” 20I7, t. XVIII, s. 249. Położenie Marchlewszczyzny, jak potocznie nazywano polski rejon narodowościowy, w pobliżu granicy z Rzeczpospolitą miało w zamyśle radzieckich władz stanowić element polityki komunistycznego oddziaływania na mieszkających po drugiej stronie granicy Polaków. Nad całością programu tworzenia „polskiego społeczeństwa socjalistycznego” miały czuwać partia bolszewicka i działające w jej strukturze polskie biura. Tamże, s. 25 I.

25 H. Stroński, 75 lat temu na Ukrainie... o represjach stalinizmu wobec Polaków w latach $30 . X X$ wieku, "Przegląd Wschodnioeuropejski” 2013, nr 4, s. 93. 
pochodzenia w zakładach kolejowych w Hreczanach. Ostatecznie projekt został zaniechany ze względu na zmianę polityki narodowościowej partii bolszewickiej. Wydaje się, że na ostateczne odstąpienie od realizacji projektu mogły również wpłynąć: stan zaawansowania kolektywizacji oraz brak wyraźnych efektów w sowietyzacji ludności polskiej na Marchlewszczyźnie ${ }^{26}$.

W 1929 r. skolektywizowane gospodarstwa rolne zajmowały na terenie Ukrainy zaledwie 8,8\% powierzchni ziem rolnych. Komuniści uznali zagłównego winowajcę tego stanu rzeczy kułaków, którzy stanowili według nich podstawowe źródło oporu przed uspołecznieniem gospodarstw. Chcąc złamać niezależność ekonomiczną chłopstwa, władze centralne przyjęły postanowienie o siłowym rozwiązaniu problemu kolektywizacji. Drogą do tego miało być rozkułaczanie, czyli pozbawienie ich ziemi, zabudowań, inwentarza oraz wszelkiego majątku ruchomego, co stanowić miało zalążek przyszłego kołchozu, do którego mogliby przyłączyć się tzw. biedniacy oraz średniacy. Przyjmując kryteria społeczno-ekonomiczne, początkowo do kułaków zaliczano zamożnych gospodarzy posiadających najemną siłę roboczą, dzierżawiących ziemię lub posiadających stosunkowo dużą liczbę zwierząt inwentarskich. Zimą 1930 r. władze komunistyczne określiły nowe zasady rozkułaczania oraz podziału kułaków na trzy kategorie. Do pierwszej kategorii zaliczono rodziny gospodarzy, którzy uczestniczyli w antysowieckich wystąpieniach bądź stawiali czynny opór władzy komunistycznej. Zgodnie z wytycznymi, odbierano im ziemię oraz majątek ruchomy, a ich samych skazywano na przesiedlenie do obozu pracy - łagru. Do drugiej grupy zaliczono osoby, które w sposób mniej aktywny przeciwstawiały się władzy sowieckiej. W tym wypadku po odebraniu ziemi i zabudowań przesiedlano ich na Syberię lub na daleką północ ZSRR, dając prawo do zabrania rzeczy osobistych i zapasów żywności. Trzecią grupę stanowili tzw. łagodni kułacy, których po rozkułaczeniu nie przyjmowano do kołchozu, ale mogli oni pozostać na Ukrainie, dostając przydziały gospodarstw poza granicami kołchozu ${ }^{27}$.

W tym samym czasie, w końcu lat 20. XX w., położenie ludności polskiej na Ukrainie, zwłaszcza na terenach przygranicznych z Rzeczpospolitą, komplikowało się. Pogorszenie sytuacji ekonomicznej wskutek stalinowskich eksperymentów narodowo-gospodarczych wywołało wśród Polaków eskalację nastrojów emigracyjnych, pasywność społeczną, protesty i opór. Sprzyjało temu dość dobre poinformowanie ludności wiejskiej, szczególnie wsi nadbużańskich, na temat warunków życia po polskiej stronie granicy oraz panującego tam systemu politycznego i gospodarczego. Jako przykład

\footnotetext{
26 Deportacje ludności polskiej do Kazachstanu w I936 roku. Zarys historyczny, Warszawa 2016, s. 6.

27 Tamże, s. I 4 .
} 
narastającego niezadowolenia można przytoczyć sytuację ze wsi Niemyrynce na Proskurowszczyźnie ${ }^{28}$ na Podolu - doprowadzeni do rozpaczy polscy chłopi z obrazami i chorągwiami usiłowali całą społecznością przejść rzekę Zbrucz, by w ten sposób dostać się na stronę polską i ujść przed władzą radziecką. Z kolei we wsi Niemyczyńce Polacy rozgromili radę wiejską, wyzwolili rozkułaczonych współmieszkańców i stawili zbrojny opór przedstawicielom władzy. Inni, zwłaszcza mający krewnych w Polsce, składali podania o zgodę na wyjazd do kraju ${ }^{29}$.

Komuniści w walce o kolektywizację wsi podejmowali różnorodne metody działania. Swoistym zabiegiem stało się tworzenie polskich kołchozów narodowościowych. Działania te przyniosły poprawę poziomu procesu kolektywizacji. Polacy częściej oddawali swe gospodarstwa do wspólnego użytkowania, gdy mogli pracować we własnym gronie, rosła również, w porównaniu do kołchozów mieszanych narodowościowo, wydajność pracy i wysokość płac. Argumentem za tworzeniem odrębnych kołchozów dla ludności polskiej były również negatywne doświadczenia z kołchozów mieszanych, w których narastały animozje i spory pogłębiające się wraz ze zdecydowanie wrogą postawą lokalnego aparatu partyjnego, z którego usunięto działaczy polskich. Jako zachętę do udziału w kolektywizacji w pasie przygranicznym stosowano dla kołchozów polskich system różnorodnych ulg. Nowe formy zachęty do zrzeszania się nie wyeliminowały dotychczasowych metod - nadal stosowano brutalną przemoc, kontynuowano „przykładowe” rozkułaczanie, pozostawiano rodziny wywiezionych czy zamordowanych kułaków w dramatycznej sytuacji bytowej, bez odzieży, butów i żywności ${ }^{3 \circ}$.

\section{Kolektywizacja na Podolu - polskie kołchozy narodowościowe}

Definiując obszar Podola w latach 20. i 30. Xx w., należy odnieść się do terenów guberni podolskiej - w latach I92I-I923 jednostki administracyjnej USRR. W roku 1923 utworzono z niej sześć okręgów: hajsyński, kamieniecki, mohylowski, płoskirowski, tulczyński i winnicki. W lutym 1932 r., zgodnie z nowym podziałem administracyjnym znalazły się one w obwodzie winnickim. Przedmiotem rozważań dotyczących kolektywizacji na tym

28 Proskurowszczyzna - obszar w obecnym obwodzie chmielnickim (ukr. Хмельницький, Chmelnyćkyj) w zachodniej części Ukrainy nad górnym Bohem przy ujściu rzeki Płoskoj. Nazwa pochodzi od miejscowości Płoskirów, ukr. Проскурів, Proskuriw (od 1954 r. Chmelnyćkyj). W omawianym okresie był to okręg administracyjny w guberni podolskiej (od $1932 \mathrm{w}$ obwodzie winnickim).

29 H. Stroński, Nieudany eksperyment..., s. 27; tenże, 75 lat..., s. 103.

30 Tenże, Represje stalinizmu wobec ludności..., s. 108-109. 
obszarze i tworzenia polskich kołchozów narodowościowych będą dwa z nich: płoskirowski i kamieniecki.

W 1924 r. na mocy postanowienia $O$ wydzieleniu narodowościowych rejonów i rad władze Ukraińskiej Socjalistycznej Republiki Radzieckiej podjęły decyzję o utworzeniu na Podolu polskich rad wiejskich. Postanowienie dotyczyło ośmiu punktów rejonu płoskirowskiego, kamieniecko-podolskiego i winnickiego. Czynnikiem, który radykalnie przyśpieszył proces tworzenia wiejskich rad narodowościowych, była vi sesja Wszechukraińskiego Komitetu Wykonawczego Ukrainy w 1925 r., na której podjęto uchwałę O oddolnym rejonowaniu. W wyniku tego postanowienia zmniejszono liczbę osób niezbędną do utworzenia rad wiejskich z 1000 do 500 mieszkańców, a dla całego rejonu z 25 tys. do Io tys. W rezultacie tych zabiegów ilość rad gminnych na Podolu zwiększyła się ${ }^{3 x}$.

Okręg kamieniecki (kamieniecko-podolski) zajmował powierzchnię $5559,6 \mathrm{~km}^{2}$ i liczył 724 wioski. Według spisu powszechnego z lat $1925-1926$ na jego obszarze mieszkało 25560 osób pochodzenia polskiego. Dane rejestru ludności budzą wątpliwości. Można przypuszczać, że w sytuacji gdy władzy bolszewickiej zależało na asymilacji mniejszości narodowych, były one zaniżane. Wiadomo, że w $1926 \mathrm{r}$. podczas powszechnego spisu ludności kwalifikowano Polaków do innych grup etnicznych, najczęściej Ukraińców, uzasadniając: „Polacy są w Polsce, a tu Ukraińcy-katolicy”. Tak przeprowadzony spis wywoływał sprzeciwy polskich mieszkańców wsi nie tylko na Podolu ${ }^{32}$. Były one nieskuteczne.

TAB. 1 Skład wiejskich rad w okręgu kamieniecko-podolskim w latach 1925-1927

\begin{tabular}{|c|c|c|c|c|}
\hline Narodowość & $1925 / 1926$ & $\%$ & $1926 / 1927$ & $\%$ \\
\hline Ukraińcy & 4732 & 88,4 & 4617 & 87,5 \\
\hline Żydzi & 291 & 5,4 & 310 & 5,9 \\
\hline Polacy & 203 & 3,8 & 226 & 4,3 \\
\hline Rosjanie & 101 & 1,9 & 105 & 2,0 \\
\hline Inni & 27 & 0,5 & 16 & 0,3 \\
\hline
\end{tabular}

Źródło: Національна Книга пам'ятіжертв Голодомору 1932-1933 рр. В Україні. Хмельнищька область, Хмемьницький 2008, s. 63.

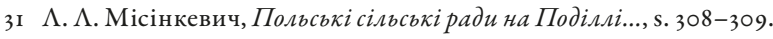

32 Zob. W. Sergiejczuk, Represje przeciwko Polakom na Ukrainie w latach 1920-193o w świetle najnowszych materiatów archiwalnych, [w:] Polska droga do Kazachstanu..., s. 4I. 


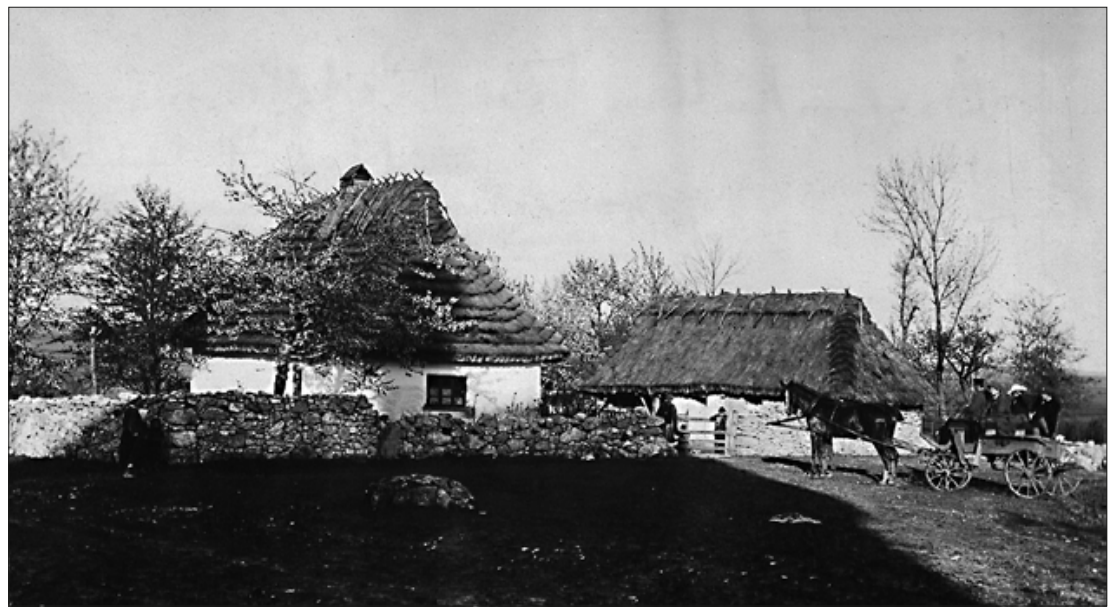

FOT. 1 Chłopska chata na Podolu (źródło: Narodowe Archiwum Cyfrowe)

W okręgu kamieniecko-podolskim w roku i925 funkcjonowało dwanaście rad narodowościowych, a w końcu roku 1926 istniały już 22 rady, wśród nich 8 stanowiły rady polskie, $\mathbf{3}$ - żydowskie i I - rosyjska ${ }^{33}$.

Bezspornie kolektywizacja rolnictwa doprowadziła do biedy ukraińską wieś. Według danych z 1924 r. 68,7\% gospodarstw Podola należało do ludzi niezamożnych, 26,7\% do średniozamożnych i tylko 4,6\% do zamożnych. Kolejnym czynnikiem przyczyniającym się do biedy wśród mieszkańców podolskiej wsi była wysokość opłacanych podatków. Wynikało to również z braku wystarczającej liczby zwierząt wykorzystywanych do prac gospodarczych, np. na dzień I 4 I 1925 r. w byłej guberni podolskiej 60,5\% gospodarstw nie posiadało zwierząt pracujących w polu. Rok później ich ilość zmniejszyła się do 33\%. W I 924 r. w okręgu kamieniecko-podolskim 63,I\% dworów nie posiadało zwierząt pracujących w gospodarstwie. Nieco lepszą sytuację notowano w okręgu płoskirowskim, gdzie odsetek ten wynosił 47,I \%. Własnymi siłami zwierząt pociągowych mogły one obrobić ziemię stanowiącą 19,4\% obszaru należącego do wszystkich dworów. Reszta zwierząt była najmowana, w następstwie czego tylko w 1924 r. 3,8\% pól przeznaczonych na zboża ozime nie została obsiana. Do połowy lat 20. na Podolu odnotowano także znaczny spadek pogłowia koni - w 1925 r. było ich 395 tys. podczas gdy w I913 r. - 565 . Wszechobecna bieda zmuszała mieszkańców wsi do poszukiwania lepszego życia w miastach, gdzie najczęściej zostawali bezrobotnymi ${ }^{34}$.

33 М. Вавринчук, С. Маркова, Голодомор на Хмельниччині Якрезультат класово боротьби та соціального експериментаторства більшовиків в 20-3о-X роках XX століття, [w:] Національна Книга..., s. 63.

34 Tamże, s. 60. 
Jak zasygnalizowano wyżej, położenie ludności wiejskiej dodatkowo pogarszały obciążenia finansowe gospodarstw. Należy podkreślić, że podatki nałożone na ludność wiejską były niewspółmiernie wysokie w stosunku do dochodów, a kary za ich nieplacenie bardzo surowe, włącznie z konfiskatą majątku i więzieniem. W latach 1925-1926 podatku w formie pieniężnej nie zapłaciła piąta część gospodarstw wiejskich, czyli wszyscy niezamożni chłopi ${ }^{35}$.

$\mathrm{Na}$ obszarze rejonu kamienieckiego w $1926 \mathrm{r}$. utworzono polski kołchoz narodowościowy. Posiadane informacje pozwalają na stwierdzenie, że prowadziło go dziesięć polskich rodzin, w sumie 43 osoby. W skład ich gospodarstwa wchodziło 50 dziesięcin ziemi (około 55 ha), osiem koni i siedem krów ${ }^{36}$.

TAB. 2 Organizacja gospodarstw kolektywnych w okręgu kamienieckim w latach $1921-1927$

\begin{tabular}{|c|c|c|c|c|c|c|c|}
\hline $\begin{array}{c}\text { Forma kolektywnego } \\
\text { gospodarstwa }\end{array}$ & 1921 & 1923 & 1924 & 1925 & 1926 & 1927 & $\begin{array}{c}\text { Ilość } \\
\text { członków }\end{array}$ \\
\hline Gmina (komuna) & - & 4 & 5 & 6 & 6 & 4 & 182 \\
\hline Spółdzielnie rolnicze & 1 & 43 & 62 & 71 & 52 & 50 & 1766 \\
\hline $\begin{array}{c}\text { Towarzystwo } \\
\text { Wspólnej Uprawy Ziemi }\end{array}$ & - & - & - & 2 & 12 & 230 & 9243 \\
\hline $\begin{array}{c}\text { Towarzystwo } \\
\text { maszynowo-traktorowe }\end{array}$ & - & - & - & - & 1 & 21 & 608 \\
\hline Razem & 1 & 47 & 67 & 79 & 71 & 305 & 11840 \\
\hline
\end{tabular}

Źródło: Національна Книга пам'яті жертв Голодомору г932-I9з3 рр. В Украӥні. Хмельницька область, Хмемьницький 2008 , s. 63.

W początkowych latach kolektywizacji rolnictwa największą popularnością cieszyły się spółdzielnie rolnicze zrzeszające chłopów na zasadzie dobrowolnego członkostwa. Od 1927 r. najwięcej osób należało do Towarzystwa Wspólnej Uprawy Ziemi. Wszystkie z przywołanych w tabeli 2 form kolektywizacji - gminy rolne, spółdzielnie, Towarzystwo Wspólnej Uprawy Ziemi i inne stowarzyszenia - miały na celu jak najszybsze uspołecznienie ziemi w myśl programu rolniczego partii bolszewickiej.

Przyzwyczajeni przez pokolenia do walki z caratem o własną ziemię polscy gospodarze nie chcieli wstępować do kołchozów. W 1932 r., czyli już w trakcie akcji kolektywizacyjnej na sowieckim Podolu, poziom uspółdziel-

35 Tamże, s. 6r.

36 А.Б. Кушнір, Польське населення на терені Хмельничини: сторінки історії, [w:] Поляки на Хмельниччині: погляд крізь віки. Збірник наукових праць за матеріаламиміжнародної конференцї̈ (23-24 червня г999 року), Хмемьницький г999, s. 7І. 
czenia obejmował średnio $62 \%$ ogółu gospodarstw, jednak we wsiach polskich wynosił on tylko $48,3 \%$. Oprócz negatywnej postawy ludności polskiej istotny wpływ na obniżenie stopnia wstępowania do kołchozów miał system chutorów (odosobnionych, niewielkich punktów osadniczych), w których żyła znacząca część polskich gospodarzy.

Na początku lat 30. XX w. część gospodarzy, którzy wcześniej złożyli swój akces do kolektywnych gospodarstw, starała się je opuścić składając odpowiednie pisma do władz. W samym rejonie kamienieckim złożono 280 podań z prośbą o zgodę na wystąpienie z kołchozu. Najczęściej jako powód podawano biedę, brak żywności i niedostatek. Jednak wyjście z kołchozu nie było proste, oddanej ziemi pod uprawy nie zwracano. Chłopi mogli nie otrzymać zwrotu swoich narzędzi pracy oraz zboża pod wysiew. Pomimo to wieśniacy decydowali się na opuszczenie kołchozów. Tylko w rejonie proskuriwskim w 1932 r. I50 rodzin dobrowolnie wyszło z kołchozów, a 250 zostało wykluczonych z powodu tego, iż - jak to nazwano - byli „obcymi agentami” ${ }^{37}$.

Podobnie niechętny stosunek do kolektywizacji przejawiali mieszkańcy polskiego rejonu narodowościowego, Marchlewszczyzny. W tej sytuacji prowadzona przez komunistów polityka „kija i marchewki” w szybkim tempie doprowadziła do prawie zupełnej kolektywizacji indywidualnych gospodarstw należących do Polaków. W I93I r. działały zaledwie 63 polskie kołchozy na terenie 170 polskich rad narodowościowych, co świadczyło o niskim stopniu kolektywizacji na tle całej Ukrainy. Jednak już dwa lata później bezwzględna polityka władz komunistycznych doprowadziła do skolektywizowania polskich gospodarstw na poziomie $95-97 \%{ }^{38}$.

\section{Skutki kolektywizacji}

Zdaniem historyków, J. Stalin zdawał sobie doskonale sprawę z tego, że nakazana przez niego „likwidacja kułactwa jako klasy” oznaczała biologiczną zagładę najważniejszej dla państwa z punktu widzenia ekonomii produkcyjnej grupy społecznej i wyrok śmierci dla milionów ludzi. Zaliczenie do skazanych na eksterminację „kułaków”, „podkułaczników”, „wrogów ludu” na wsi nie opierało się na posiadaniu przez nich własności rolnej. Byli do nich zaliczani umierający z głodu nędzarze, jeśli tak zostali określeni z jakiegokolwiek powodu przez donosiciela lub miejscową władzę wiejską, np. $\mathrm{z}$ racji posiadanego wykształcenia, polskiego pochodzenia, ukrycia resztek żywności przed konfiskatą, słowa skargi na panujący stan rzeczy itp.

37 М. Вавринчук, С. Маркова, dz. cyt., s. 73.

38 Deportacje ludności polskiej do Kazachstanu..., s. I5. 
zarzutów. Należy podkreślić, że bezpośrednim celem kolektywizacji było złamanie oporu ludności wiejskiej przeciwko kołchozom, a w dalszej perspektywie zniszczenie dążeń narodowych i niepodległościowych Ukrainy ${ }^{39}$.

Dowodem bezwzględności władz bolszewickich w realizowaniu planu kolektywizacji był dekret z 7 VII 1932 r. o karze śmierci i więzienia „za wszelką kradzież lub roztrwonienie socjalistycznej własności", nazwany przezludność wiejską „prawem pięciu kłosów”. Z nastaniem lata ludzie nocami usiłowali ścinać kłosy dojrzewającego zboża lub potajemnie je zbierać na polu, już po jego skoszeniu i zebraniu, by zdobyć odrobinę pożywienia. Władze zrobiły jednak wszystko, by to uniemożliwić. Nakazano postawić na polach wieże strażnicze, na których dzień i noc czuwali uzbrojeni ludzie. Wspomagali ich krążący wciąż strażnicy naziemni. Próby zdobycia pożywienia na polu najczęściej kończyły się schwytaniem winowajcy i wyrokiem skazującym. Zazwyczaj oznaczało to zasądzenie śmierci oskarżonego, ale zwykle zamieniano ją na dziesięć lat łagrów. Niekiedy całe transporty kierowano tam bez wyroku sądu ${ }^{40}$. Dekret dotyczył również dzieci. Drakońskie prawo spełniało rolę ludobójczą, ponieważ uniemożliwiało ludziom ratowanie się przed śmiercią głodową. Władze komunistyczne ustanowiły nagrody w postaci racji żywnościowych dla donosicieli obciążających tych, którzy w jakikolwiek sposób naruszyli zarządzenia władz lub krytycznie się o nich wypowiedzieli. Od sierpnia $1932 \mathrm{r}$. do grudnia następnego roku za naruszenie wspomnianego wyżej dekretu skazano w sumie I25 tys. osób, w tym 5,4 tys. na karę śmierci ${ }^{41}$.

W grudniu 1932 r. wydano kolejne zarządzenie władz dotyczące ściągania obowiązkowych dostaw produktów rolnych. Decyzję uzasadniano wrogą działalnością kułaków, agentów polskich i innych, jak ich nazywano, kontrrewolucyjnych elementów operujących na wsi. Rozpoczęto konfiskowanie resztek ukrywanej przez ludność żywności. Na podstawie wspomnień, które w latach 90. XX w. zebrał Piotr Jaszczuk, jawi się obraz wsi ukraińskich, gdzie „brygady szturmowe” komsomolców odbierały nawet znalezione w garnkach na kuchni lub w piecu resztki pożywienia i niszczyły je. Dewastowały żarna i stępy mogące służyć do przygotowania ziarna, wybijały okna, demolowały chaty. Powszechnie towarzyszyło temu fizyczne i moralne znęcanie się nad ludźmi ${ }^{42}$. Wszystkie wspomnienia zawierały relacje podobne do opowiadania Leokadii Sidorskiej z miasteczka Połonne w obwodzie płoskirowskim: „Chodzili i w Płonnem po chatach i zabierali wszystko, co

\footnotetext{
39 R. Dzwonkowski, Gtód i represje wobec ludności polskiej..., s. 206.

40 П. Ящук, dz. cyt., t. І, Київ- Нью Йорк 1999, s. 691.

4I R. Dzwonkowski, Gtód i represje wobec ludności polskiej..., s. 206.

42 П. Ящук, dz. cyt., s. 622- 625, 629-632.
} 
można było jeść. Do nas przyszli i suszone jagody zabrali. Zabrali krowę, konie, zboże wszystkie, kartofle, buraki" 43 .

Ludność próbowała się ratować przed głodem, uciekając ze wsi do miast. Temu zdecydowanie przeciwstawily się władze komunistyczne, nakazując organom lokalnym, w szczególności wszechwładnemu GPU, „całkowite uniemożliwienie wyjazdów ludności wiejskiej z miejsca zamieszkania" ${ }^{4}$. Służyć temu miały: zakaz sprzedaży biletów kolejowych, blokady dróg, rewizje bagaży podróżnych. Mimo wprowadzenia drakońskich przepisów ludność próbowała ratować życie, podejmując zazwyczaj daremne próby zmiany miejsca zamieszkania. Przykładem może być raport GPU z marca 1933 r. opisujący rozmiary zjawiska: $w$ ciągu jednego miesiąca zatrzymano ponad 219 tys. osób, z których ponad 186 tys. zmuszono do powrotu do miejsca zamieszkania, zaś pozostałych 33 tys. aresztowano i osądzono ${ }^{45}$. Jak z powyższego wynika, następstwem polityki komunistów prowadzonej na Ukrainie była dramatyczna sytuacja aprowizacyjna ludności wiejskiej prowadząca do masowego wymierania. W sumie rozmiar śmierci głodowej wśród poszczególnych narodowości zamieszkujących Ukraińską SRR wyniósł w latach 1932-I933: spośród Ukraińców - I 522 tys. osób, Rosjan - 85 tys., Żydów - 27 tys., Polaków - 20,7 tys., Mołdawian - 16,1 tys., Niemców - 13,2 tys., Bułgarów - 7,7 tys., Greków - 2,5 tys. Ludność polska stanowiła I,I\% ogólnej liczby ofiar, jednak w zestawieniu z oficjalną liczbą Polaków w oparciu o spis ludności należy stwierdzić, że na wiosnę 1933 r. z głodu zmarło 4\% Polaków ${ }^{46}$.

W listopadzie 1934 r. Komitet Centralny Komunistycznej Partii Ukrainy (KC KPU) postanowił przeorganizować rady wiejskie. Na mocy uchwały winnickiej z 23 listopada, KPU zarządziła zmianę osiemnastu polskich rad wiejskich $\mathrm{w}$ rady ukraińskie. W ten sposób polskie rady wiejskie na Ukrainie radzieckiej przestały istnieć.

W I935 r. rozpoczęła się masowa deportacja polskiej ludności zjej miejsca zamieszkiwania. Dnia 16 X 1935 r. CK KUP podjęło decyzję o deportowaniu I,5 tys. polskich rodzin z przygranicznych rejonów obwodu winnickiego. Postanowienie to objęło swoim zasięgiem także część rejonów należących wcześniej do obwodu chmielnickiego. Polaków z tych obszarów przesiedlono do Kazachstanu ${ }^{47}$.

\footnotetext{
43 Tamże, s. 575.

44 R. Dzwonkowski, Gtód i represje wobec ludności polskiej..., s. 208.

45 S. Courtois i in., Czarna ksiega komunizmu. Zbrodnie, terror, prześladowania, Warszawa 1999, s. I62.

46 Deportacje ludności..., s. I7.

47 А. Б. Кушнір, dz. cyt., s. 7I.
} 
Proces przekształcania indywidualnych gospodarstw rolnych w spółdzielnie rolnicze na Ukrainie w latach 20. i 30 . XX w. stał się początkiem nieludzkiego cierpienia igłodu jej obywateli, w tym licznej rzeszy Polaków. Po upływie iz lat od spisu ludności z 1926 r., kolejny przeprowadzony w roku 1939 wykazal, że na 117912 obywateli zamieszkujących rejon kamieniecki było 4202 Polaków. W miastach żyło 36208 osób, z czego Polacy stanowili 2,8 \%, czyli r or 6 mieszkańców. Z kolei na wsi żyło 3 I 86 osób, czyli 3,9\% społeczności gromadzkiej. W 1939 r. w rejonie kamienieckim Polacy stanowili czwartą grupę etniczną, po Ukraińcach (92,9 tys. osób), Żydach (Is tys. osób) i Rosjanach (4,8 tys. osób) ${ }^{48}$. Różnica 2I 358 osób deklarujących narodowość polską pomiędzy danymi spisów z lat 1926 i 1939 tylko w pewien obrazowy sposób oddaje skalę martyrologii ludności. W ciągu zaledwie I3 lat sprawowania władzy na Ukrainie przez komunistów z obszaru rejonu kamienieckiego zniknęło 83,6\% ludności polskiej zamieszkującej te tereny od wieków.

Niezaprzeczalnie mechanizmy wprowadzania wymuszonej kolektywizacji przyczyniły się do eksterminacji ludności polskiej, a próby tworzenia kołchozów narodowościowych nie przyniosły oczekiwanych efektów. Polacy niechętnie wstępowali do gospodarstw kolektywnych. W I932 r. poziom uspółdzielczenia obejmował już średnio $62 \%$ ogółu gospodarstw położonych na Podolu, jednak we wsiach polskich na tym terenie wynosił on tylko $48,3 \%$. Niemniej kolektywizacja zapewniła partii komunistycznej pełną kontrolę nad życiem społecznym i prywatnym ludności wiejskiej. Mieszkańcy obszarów wiejskich zostali materialnie całkowicie uzależnieni od państwa. System totalitarny został ugruntowany i wzmocniony.

\section{Bibliografia}

\section{Źródła drukowane}

Âŝk P., Portret Temrâvi. Svî́čennâ, dokumenta i materiali (u dvoh knigah), t. I-2, Kiï-N'û Jork 1999. [Ящук П., Портрет Темряви. Свщчення, документа іматеріали (удвох книгах), t. І-2, Київ-Нью Йорк 1999.]

Lenin W., O spótdzielczości produkcyjnej na wsi, Warszawa 1949

Marks K., Engels F., Manifest Komunistyczny, Warszawa 1948.

Polacy na Ukrainie, t. 9: Zbiór dokumentów, cz. I: Lata 1917-1939, Przemyśl 2019. Vsecô̂znaâ perepis' naseleniâ I939 goda. Nacional'nyj sostav naseleniâ rajonov, gorodov $i$ krupnyh sel soûznyh respublik SSSR. [Всесоюзная перепись населения 1939 года. Наииональный состав населения районов, городов и крупных сел союзных республик CCCP.] Dostępny w Internecie: http://www.demoscope.ru/weekly/ssp/ussr_nac_39_ ra.php? reg= 179 .

48 Всесоюзная перепись населения г9з9 года. Науиональный состав населения районов, городов и крупных сел союзных республик СССР. Dostępne w Internecie: http://www.demoscope.ru/ weekly/ssp/ussr_nac_39_ra.php?reg=I79 [dostęp: Io maja 2020]. 


\section{Opracowania}

Bernaś F., Wilczur J.E., Piekielny krag. Z dziejów CZEKA, GPU, NKWD, Warszawa b.r.w.

Conquest R., The Harvest of Sorrow. Soviet collectivization and the terror-famine, New York-Oxford 1986.

Courtois S. i in., Czarna księga komunizmu. Zbrodnie, terror, prześladowania, Warszawa 1999.

Cwietkow G.P., Sowieckie ustawodawstwo i organy represji w latach 20-30. XX wieku, „Zesłaniec” 2008, nr 33.

Deportacje ludności polskiej do Kazachstanu w 1936 roku. Zarys historyczny, Warszawa 2016.

Dzwonkowski R., Gtód i represje wobec ludności polskiej na Ukrainie (1932-1933, 1946-1947), „Teka Komisji Historycznej” Polska Akademia Nauk Oddział w Lublinie 20I2, vol. Ix.

Dzwonkowski R., Marchlewszczyzna, [w:] Encyklopedia Katolicka, t. II, Lublin 2006.

Iwanow M., Pierwszy naród ukarany. Polacy w Zwiąku Radzieckim 192I-1939, Warszawa 1991.

Kalinowski Z., Materyaty do architektury polskiej. Wieś i miasteczko, t. I, Warszawa 1916.

Kulczycki S., Hotodomor. Wielki gtód na Ukrainie w latach 1932-1933 jako ludobójstwo-problem świadomości, przekład B. Salej, Wrocław 2008.

Kupczak J. M., Polacy na Ukrainie w latach 1921-1939, „Acta Universitatis Wratislaviensis. Politologia" 1994, t. XII.

Kuśnierz R., Ukraina w latach kolektywizacji i Wielkiego Gtodu (I929-1933), Toruń 2005.

Kušnìr L. B., Pol's'ke naselennâ na tereni Hmel'niččini: stopinki istorï, [w:] Polâki na Hmel'ničcini: poglâd kriz viki. Zbirnik naukovih prac'za materialami mižnarodnoï konferencï̈ (23-24 červnâ I9g9 roku), Hmel'nic'kij 1999. [Кушнір А. Б., Польське населення на терені Хмельниччини: сторінки історії, [w:] Поляки на Хмельниччині: погляд крізь віки. Збірник наукових праць за матеріалами міжнародної конферениії (23-24 червня 1999 року), Хмемьницький 1999.]

Luszniewicz J., Gospodarka radziecka w latach I9I7-194I, [w:] Powszechna historia gospodarcza I9I8-I9gI, pod red. W. Morawskiego, Warszawa 1994.

Micinkevič L., Evrejs'ka ipol's'ka nacional'ni menšini Podillâ (2o-30 ti rr. XX stolittâ),

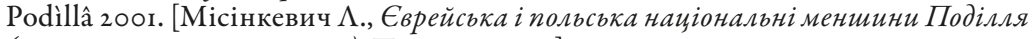

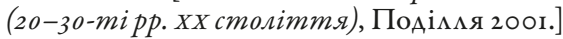

Mìcìnkevič L., Korenizaciâ i nacional'ni menšini Podillâu u 20-3o-h rr. XX stolittâ,

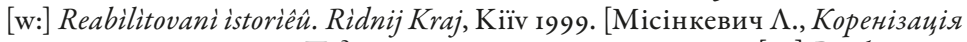
інаціональні меншини Поділяя у го-30-х рр. ХХ столітmя, [w:] Реабілітовані історією. Рідний Край, Київ 1999.]

Mìcinkevič L., Pol'ski sil's'ki radi na Podilliv v 1920-1930-ti roki, [w:] Polâki na Hmel'niččini: poglâd kriz viki. Zbirnik naukovih prac'za materialami mižnarodnö̈ konferencii (23-24 červnâ 19g9 roku), Hmel'nic'kij 1999. [Місінкевич $\Lambda$., Польські сільські ради на Поділлі в гого-г9зо-ті роки, [w:] Поляки на Хмельниччині: погляд крізь віки. Збірник наукових пращь за матеріалами міжнародної конференщї (23-24 червня 1999 року), Хмемьницький 1999.]

Mìcinkevič L., Procesi reabilitacï v Ukraïni žertv političnih represij radâns'koï dobi, [w:] Reabilitovani istoriêû. Hmel'nic'ka oblast', t. 27, Hmel'nic'kij 2015. [Місінкевич $\Lambda$., Прочеси реабілітацї в Украӥні жертв політичних репресій радянськоїдоби, [w:] Реабілітовані історією. Хмельнищька область, t. 27, Хмемьницький 2015.]

Mììnkevič L., Reabilitaciâ žertv politučnih represij v Ukraïni druga polovina XX - počatok XXI stolittâ), Hmel'nic'kij 2009. [Місінкевич $\Lambda .$, Реабілітачіл жертв політичних репресій в Україні (друга половина ХХ - початок ХХІ столітmя), Хмемьницький 2009.]

Sergijczuk W., Represje przeciwko Polakom na Ukrainie w latach $1920-1930$ w siwietle najnowszych materiatów archiwalnych, [w:] Polska droga do Kazachstanu. Materiaty z międzynarodowej konferencji naukowej. Żytomierz I2-I4 października 19g6r., Warszawa 1998.

Slobodânûk P. Â., Golodomori v Ukraïi âk zasib vinisisennâ Ukraïnstva, [w:] Nacional'na Kniga pam'âti žertv Golodomoru 1932-1933 rr. v Ukraïni. Hmel'nic'ka oblast', 
BARBARA JANUSZKIEWICZ Tworzenie polskich kołchozów narodowościowych w ramach kolektywizacji...

Hmel'nic'kij 2008. [Слободянюк П. Я., Голодомори в Україні як засіб винищення Украйнства, [w:] Національна Книга пам'яті жертв Голодомору 1932-I933 рр. В Україні. Хмельницька область, Хмельницький 2008.]

Smoleń M., Kolektywizacja rolnictwa w ZSRR, [w:] Encyklopedia „biatych plam”, Radom 2002.

Stroński H., 75 lat temu na Ukrainie... o represjach stalinizmu wobec Polaków w latach 30. XX wieku, „Przegląd Wschodnioeuropejski” 2013, nr 4.

Stroński H., Marchlewszczyzna. Rzecz o Polskim Rejonie Narodowościowym na Ukrainie w latach 1925-1935, „Echa Przeszłości” 2017, t. XVIII.

Stroński H., Nieudany eksperyment. Treść, formy i skutki sowietyzacji ludności polskiej na Ukrainie w latach dwudziestych i trzydziestych XX wieku, [w:] Polska droga do Kazachstanu. Materiaty z międzynarodowej konferencji naukowej, Żytomierz I2-I4 października 19g6 $r$., Warszawa 1998.

Stroński H., Represje stalinizmu wobec ludności polskiej na Ukrainie w latach 1929-1939, Warszawa 1998.

Synder T., Skrwawione ziemie. Europa między Hitlerem a Stalinem, przekład B. Pietrzyk, Kraków 2018.

Vavpinčuk M., Markova S., Golodomor na Hmel'niččini. Âk rezul'tat klasowo borot'bi ta sočial'nogo eksperimentatorstva bil's'sovikiv v 20-30-X rokah XX stolittâ, [w:] Načional'na Kniga pom'âti žertv Golodomoru 1932-1933 rr. v Ukraïni, Hmel'nic'kij 2008. [Вавринчук М., Маркова С., Голодомор на Хмельниччині. Якрезультат класово боротьби та сочіального експериментаторства більшовиків в го-зо-х роках XX столітmя, [w:] Національна Книга пам'яті жертв Голодомору 1932-1933 рр. В Україні. Хмельницька область, Хмемьницький 20о8.]

Streszczenie: Jedną z najważniejszych części „leninowskiej polityki” w latach 2o. i na początku lat 30. XX w. była kolektywizacja rolnictwa, przewidująca tworzenie tzw. kolektywnych gospodarstw. Kołchozy powstawały w wyniku przymusowego przejęcia ziemi od indywidualnych rolników nazywanych „kułakami”. Zakładanie kołchozów na Ukrainie napotykało na największy opór miejscowej ludności, szczególnie ludności polskiej, której liczne skupiska istniały m.in. w obwodzie kamieniecko-podolskim. Dowodem bezwzględności władz bolszewickich w realizowaniu planu kolektywizacji był dekret z 7 VIII 1932 r. o karze śmierci i więzienia „za wszelką kradzież lub roztrwonienie socjalistycznej własności”, nazwany przez ludność wiejską "prawem pięciu kłosów”. W celu przełamania czynnego i biernego oporu przeciwko uwłaszczeniu ludności wiejskiej władze celowo, w sposób wymuszony, wywołały „wielki głód”, który spowodował śmierć 5-6 mln ludzi.

Słowa klucze: kolektywizacja, kołchoz, kułak, Podole, polityka narodowościowa

Summary: One of the most important part of Leninist policy in the I920s and the early I930s was collectivization of agriculture whose aim was the creation of so-called collective farms. Kolkhozes were created as a result of a forced takeover of land from farmers called "kulaki". The establishment of collective farms in Ukraine faced the greatest resistance of the civilian population, especially the Polish population whose numerous clusters existed in the Podole region. Evidence of the authorities ruthlessness in implementing the collectivization plan was a decree from August 71932 about the death penalty and prison - "for stealing and wasting socialist property". This document was called "law of five ears". In order to break the resistance against enfranchisement of the population, the authorities intentionally evoked "great hunger" which caused the deaths of six million people.

Keywords: collectivization, kolkhoz, kulak, Podole, nationality policy 